\title{
Biblioteki włoskie - między tradycją a nowoczesnością
}

\begin{abstract}
Streszczenie. Przez wieki na terenie dzisiejszej Republiki Włoch powstawały najświetniejsze biblioteki w Europie. Od średniowiecza po renesans prężnie się rozwijały i odgrywały dominującą rolę na Starym Kontynencie. Artykuł przedstawia, jak włoskie biblioteki funkcjonują dziś. Poruszając takie zagadnienia, jak: typy bibliotek we Włoszech i współpraca między nimi, normy prawne, którym podlegaja, działalność bibliotek narodowych, stowarzyszenia bibliotekarskie, inicjatywy i projekty wykorzystujące w bibliotekarstwie najnowsze techniki informatyczne, podkreśla słabe i mocne strony bibliotekarstwa włoskiego i przywołuje refleksję: jaka jest rola bibliotek włoskich dziś, kiedy lata ich rozkwitu minęły, i czy są one w stanie sprostać wymaganiom współczesności.
\end{abstract}

SŁowA KLuczowE: biblioteki, bibliotekarze, problemy współczesnych bibliotek, włoskie biblioteki, współczesne biblioteki włoskie.

Na hasło: biblioteki włoskie, przychodzi na myśl ich długa i bogata historia. Włochy, obok Anglii czy Francji, stanowią kolebkę bibliotek w Europie. Historyczne znaczenie włoskich bibliotek jest niezaprzeczalne. Początki bibliotek sięgają czasów antycznych. Pierwsze księgozbiory były sprowadzane do starożytnego Rzymu jako zdobycze wojenne z Grecji, z czasem - gdy wśród bogatych Rzymian zapanowała moda na zbieranie książek - zaczęły powstawać liczne prywatne biblioteki, niektóre z tych kolekcji liczyły kilka tysięcy jednostek.

W średniowieczu na terenie Włoch powstawały liczne biblioteki klasztorne, a przy pierwszych uniwersytetach biblioteki uczelniane. Działalność jednej z takich średniowiecznych bibliotek, funkcjonującej w opactwie benedyktyńskim w północnych Włoszech w 1327 roku, opisał w powieści Imię róży Umberto Eco. Biblioteki włoskie rozwijały się również $\mathrm{w}$ renesansie, w dobie Gutenberga. Kiedy w Europie zaczęły królować książki drukowane, w Italii powstawały jedne z pierwszych bibliotek publicznych 
w Europie. Przybywało też prywatnych kolekcjonerów i fundatorów nowych książnic ${ }^{1}$.

Dziś Włochy mogą poszczycić się świadectwami tej historii, bogatym dziedzictwem kulturowym, a także pięknymi, starymi bibliotekami o długich tradycjach, takimi jak stworzona w 1606 roku przez Fryderyka Boromeusza Biblioteka Ambrozjańska w Mediolanie, jedna z pierwszych bibliotek publicznych w Europie, biblioteka Marciana w Wenecji, stworzona z kolekcji kardynała Bessariona, przekazanej Wenecjanom w 1468 roku, czy biblioteka Malatestiana w Cesenie, założona w XV wieku, pierwsza biblioteka miejska w Europie. Każda z nich zachwyca nie tylko pięknymi, zabytkowymi wnętrzami, ale też bogactwem i świetnością zbiorów. W Bibliotece Ambrozjańskiej można znaleźć na przykład Kanon Muratoriego (najwcześniejszy katalog ksiąg Nowego Testamentu) i Codex Atlanticus Leonarda da Vinci, a w bibliotece Marciana dwa najsłynniejsze rękopisy Iliady pochodzące z X i XI wieku: L'Homery Venetus i L'Homerus Venetus B.

Nie historia jednak, choć tak ciekawa i bogata, będzie w niniejszym tekście przedmiotem mojej uwagi. Chciałabym się skupić przede wszystkim na współczesnych bibliotekach włoskich. Jest to w Polsce zagadnienie rzadko poruszane, a przecież chodzi o jedno z najważniejszych państw współczesnej Europy. Interesować mnie będzie sposób funkcjonowania wielkich bibliotek, funkcje, jakie spełniaja, ich wewnętrzne zróżnicowanie, miejsce zajmowane w społeczeństwie, regulacje prawne, którym podlegaja, kłopoty i problemy, z jakimi przychodzi się im mierzyć, systemy udostępniania itp. Odwoływać się będę do włoskich tekstów z zakresu współczesnego bibliotekoznawstwa i własnych obserwacji poczynionych w czasie pobytu we Włoszech w ramach programu Erasmus.

Oczywiście nie uda się całkowicie porzucić kontekstu historycznego, ponieważ ma on niewątpliwie wpływ na funkcjonowanie systemu, według którego działają obecnie włoskie biblioteki, a z rozmaitych uwarunkowań historycznych wynikają problemy, z którymi zmagają się współcześni włoscy bibliotekarze.

Włochy jako zjednoczone państwo istnieją od niedawna, od 1861 roku. Przed tą datą Półwysep Apeniński, mimo że był względnie spójny pod względem językowym i kulturowym, składał się z niezależnych republik i księstw oraz obcych posiadłości i stref wpływów. Konsekwencje tych podziałów są widoczne w Italii do dziś i znajdują odbicie w funkcjonowaniu włoskiej administracji, której podlegają również biblioteki.

${ }^{1}$ Historia bibliotek [online], [dostęp: 1.03.2011], dostępny w internecie: www. biblios.info/wiedza/historia-bibliotek. 
Państwo włoskie podzielone jest na 20 regionów, które cieszą się znaczną autonomią. Mimo że są one zobowiązane do współpracy z administracją państwową konstytucja zapewnia im dużą niezależność działania w wielu sferach. Co więcej, pięć z nich, Dolina Aosty, Friuli-Wenecja Julijska, Sardynia, Sycylia oraz Trydent, działa na szczególnych prawach, wynikających między innymi z obecności różnych mniejszości narodowych i pozwalających im na stanowienie prawa $\mathrm{w}$ niektórych dodatkowych sferach. Samodzielność poszczególnych regionów nie zawsze jednak dobrze wpływa na współpracę między nimi i na koordynację działań, które podejmują. Można się o tym przekonać, przyglądając się bliżej, w jaki sposób funkcjonują podlegające tym regionom biblioteki.

Ich struktura jest oparta na Regolamento recante norme sulle biblioteche publiche statali (Rozporządzenie ustanawiające zasady dotyczące bibliotek publicznych państwowych). Dokument ten został wydany po raz pierwszy w 1859 roku, a następnie po zjednoczeniu Włoch był kilkakrotnie modyfikowany w latach 1869, 1876, 1885, 1907 i 1967. Obowiązująca obecnie wersja pochodzi z 5 lipca 1995 roku²$^{2}$. Można powiedzieć, że jest to odpowiednik polskiej Ustawy o bibliotekach. W odróżnieniu od niej nie dotyczy jednak wszystkich typów bibliotek, ale jedynie tych określanych mianem "pubbliche statali", czyli biblioteki publiczne państwowe. Do tej grupy należy 46 instytucji, wśród których znajdują się największe i najważniejsze biblioteki w Italii, m.in. biblioteki narodowe (o których dokładniej w dalszej części artykułu), dziewięć bibliotek uniwersyteckich, niepodlegających bezpośrednio uniwersytetom, w Genui, Padwie, Pavii, Modenie, Pizie, Neapolu, Cagliari, Sassari i Biblioteka Aleksandryjska w Rzymie, jedenaście bibliotek zaliczonych do zabytków narodowych i szesnaście innych, np. Biblioteca Reale w Turynie, Biblioteca Marucelliana, Biblioteca Riccardiana i Biblioteca Medicea Laurenziana we Florencji, Biblioteca Angelica, Biblioteca Baldini, Biblioteca Casanatense w Rzymie. Wymienione wyżej instytucje podlegają bezpośrednio władzom państwowym i pieczę nad nimi sprawują Ministerstwo Kultury oraz działająca przy nim Direzione Generale per le Biblioteche, gli Istituti Culturali e il Diritto d' Autore (Generalna Dyrekcja do spraw Dóbr Kultury, Instytutów Kulturalnych i Prawa Autorskiego).

Działania owej dyrekcji dotyczą nie tylko działalności bibliotek, ale też działalności kulturalnej w szerokim rozumieniu tego słowa. Najważniejsze $\mathrm{z}$ nich to: promocja czytelnictwa i użytkowania bibliotek w kraju, pomoc włoskim wydawnictwom w rozpowszechnianiu włoskiej kultury

${ }^{2}$ AIB-WEB. Il mondo delle biblioteche in rete, Legislazione statale [online], [dostęp: 1.03.2010], dostępny w internecie: www. aib.it/aib/lis/lpi08a.htm. 
za granica, nadzór nad instytucjami kultury i ogólnokrajowymi przedsięwzięciami kulturalnymi. Dyrekcja ma trzy oddziały, którym przypisane są poszczególne zadania:

1. Serivizio I - Affari generali, programazione, bilancio e personale (Oddział I - Sprawy ogólne, organizacyjne, personalne i budżetowe);

2. Servizio II - Patrimonio bibliografico ed istituti culturali (Oddział II Dziedzictwo bibliograficzne, państwowe i niepaństwowe);

3. Servizio III - Diritto d'autore e vigilianza sulla SIAE (Oddział III Prawo autorskie i piecza nad SIAE - Societa Italiana Autori ed Editori - Włoskim Stowarzyszeniem Pisarzy i Wydawców).

Ponadto dyrekcja ma swoje siedziby w miejscach związanych ze środowiskiem bibliotecznym:

1. Istituto Centrale per il Catalogo Unico delle Biblioteche Italiane e per le Informazioni bibliografiche (Centralny Instytut ds. Ujednoliconego Katalogu Włoskich Bibliotek i Informacji Bibliograficznych w Rzymie);

2. Istituto Centrale per i Beni Sonori e Audiovisivi (Instytut Centralny ds. Materiałów Dźwiękowych i Audiowizualnych);

3. Bibliotecha Nazionale Centrale di Roma Vittorio Emmanuele II (Centralna Biblioteka Narodowa w Rzymie);

4. Biblioteca Nazionale Centrale di Firenze (Centralna Biblioteka Narodowa we Florencji);

5. Centro per il Libro e la Lettura (Centrum Książki i Lektury w Rzymie $)^{3}$.

Direzione Generale per le Biblioteche, gli Istituti Culturali e il Diritto d' Autore działa od niedawna. Została powołana przez Dekret Prezydenta Republiki w listopadzie 2007 roku i zastąpiła istniejące do tamtej pory przy ministerstwie Ufficio Centrale per i Beni Librari e gli Istituti Culturali (Centralne Biuro ds. Źródeł Książkowych i Instytutów Kulturalnych). Obecnie przewodniczy jej Maurizio Fallace, prawnik i archiwista, dyrektor generalny Archiwum Państwowego.

W artykule pierwszym rozdziału pierwszego Regolamento Recante Norme sulle Biblioteche Pubbliche Statali można zapoznać się ze szczegółową listą bibliotek, które podlegają prawom zapisanym w tymże dokumencie ${ }^{4}$.

${ }^{3}$ Ministero per i Beni e le Attivita Culturali, Direzione Generale per le biblioteche, gli Istituti Culturali ed il diritto d'autore [online], [dostęp: 2.03.2011], dostępny w internecie: http://www.beniculturali.it/mibac/export/MiBAC/sito-MiBAC/Luogo/ Uffici/Struttura-organizzativa/visualizza_asset.html_747374523.html.

${ }^{4}$ P. Traniello, Legislazione delle biblioteche in Italia, Roma 1999, s. 30-32. 
Instytucje pominięte we włoskiej ustawie to głównie biblioteki podlegające władzom lokalnym, a więc "biblioteche di enti locali”. Biblioteki te objęte są prawem administracyjnym regionu, w którym funkcjonuja, zgodnie z opisywanym wyżej konstytucyjnym prawem autonomii lokalnej. Każdy region rządzi się własnymi aktami prawnymi dotyczącymi finansowania i zarządzania działalnością bibliotek, archiwów, instytucji kulturalnych.

Do takich bibliotek należą biblioteki miejskie, które często tworzą sieci w obrębie danego miasta lub prowincji, biblioteki publiczne, szpitalne, więzienne itp. ${ }^{5}$.

Zasady sformułowane w Regolamento... nie obowiązują także jednych z najstarszych i mających najznakomitsze zbiory bibliotek kościelnych stanowiących własność zakonów, seminariów duchownych, stowarzyszeń i akademii katolickich, pozostających pod zarządem Kościoła i instytucji kościelnych - oraz bibliotek szkolnych. Te ostatnie są niestety słabo rozwinięte we Włoszech. Rzadko można je znaleźć w szkołach podstawowych czy średnich, w przeciwieństwie do Polski, gdzie działalność biblioteki w każdej szkole jest obowiązkowa. Część placówek szkolnych posiada księgozbiory dostępne dla uczniów, często nie są one jednak uporządkowane i skatalogowane, a prowadzą je emerytowani nauczyciele. Wynika to nie tylko z braku środków finansowych, ale również z faktu, że włoskie władze oświatowe nie widzą potrzeby organizowania tego typu bibliotek, nie doceniają też funkcji, jakie mogłyby one spełniać we współczesnej szkole ${ }^{6}$.

Fakt, że nie wszystkie biblioteki podlegają tej samej ustawie i znajdują się pod zarządem różnych osób i instytucji, pogłębia podziały między nimi i utrudnia stworzenie jednolitego i sprawnie funkcjonującego systemu na skalę krajową. Jest to niewątpliwie jeden z większych problemów współczesnego włoskiego bibliotekoznawstwa. Sygnalizuje go wielu znawców tej dziedziny. Szeroko opisywany jest między innymi przez Paolo Traniellego w pracy Le biblioteche italiane di oggi (Biblioteki włoskie dziś), będącej zmodyfikowanym i rozbudowanym rozdziałem jego książki Storia delle biblioteche in Italia. Dall'Unita ad oggi (Historia bibliotek we Włoszech. Od zjednoczenia do dziś), opisującej ewolucję włoskich bibliotek od zjednoczenia państwa do początków XXI wieku. Autor podkreśla, iż rozwarstwienie jednostek administracyjnych zarządzających

${ }^{5}$ Ibidem, s. 33.

${ }^{6}$ M. Guerrini, Libraries in Italy. A Brief Overwiev, „Ifla Journal” 2009, nr 2, s. 94-116 [online], [dostęp: 1.03.2011], dostępny w internecie: http://archive.ifla.org/V/iflaj/IFLA-Journal-2-2009.pdf. 
bibliotekami sprawia, że trudno im znaleźć kompromis w dążeniu do wspólnego celu. Powstaje chaos organizacyjny. Biblioteki nie mają wyraźnie podzielonych między sobą zadań i ról. Nawet te, które znajdują się niedaleko siebie, nie potrafią współpracować i dzielić się zadaniami, brak im koordynacji w działaniu?

Duże zróżnicowanie widoczne jest też w kwestii włoskich bibliotek narodowych. W przeciwieństwie do Polski, gdzie funkcjonuje jedna Biblioteka Narodowa w Warszawie, mająca jednocześnie status biblioteki centralnej, we Włoszech istnieje ich aż dziesięć, w tym dwie biblioteki centralne, a także jedna biblioteka uniwersytecka. Są nimi:

- Biblioteca Nazionale Centrale di Roma,

- Biblioteca Nazionale Centrale di Firenze,

- Biblioteca Nazionale Sagarigga Visconti di Bari,

- Biblioteca Nazionale di Coscenza,

- Biblioteca Nazionale di Potenza,

- Biblioteca Nazionale Braidese di Milano,

- Biblioteca Nazionale Vittorio Emmanuele di Napoli,

- Biblioteca Nazionale Marziana di Venezia,

- Biblioteca Nazionale di Macerata,

- Biblioteca Nazionale Universitaria di Torino.

Istnienie tak wielu bibliotek narodowych we Włoszech ma historyczne uzasadnienie. Jeszcze przed zjednoczeniem w obrębie poszczególnych regionów funkcjonowały biblioteki, które można określić mianem narodowych. Po zjednoczeniu zadecydowano, że osiem z nich dalej będzie sprawowało powierzone im zadania pod szyldem bibliotek narodowych, reprezentując $\mathrm{w}$ ten sposób kulturę regionalną terenu, na którym się znajdują. Dwie biblioteki centralne natomiast zajmą się sprawami ogólniejszymi, będą otrzymywały, gromadziły i archiwizowały egzemplarz obowiązkowy, a także sprawowały kontrolę bibliograficzną. Mieszczą się one w byłej i w obecnej stolicy państwa, czyli we Florencji, pełniącej funkcję głównego miasta w latach 1865-1870, i w Rzymie, który pełni ją od 1870 roku do dziś. Biblioteca Nazionale di Firenze jest obecnie odpowiedzialna za bibliografię narodową Włoch. Jest też liderem $\mathrm{w}$ tworzeniu rekordów dla Servizio Bibliotecario Nazionale (SBN), czyli centralnego, zintegrowanego katalogu włoskich bibliotek. Natomiast Biblioteca Nazionale Centrale di Roma stanowi centrum informacji bibliograficznej. Od 1886 roku zajmuje się wydawaniem Bolletino delle opere moderne straniere (Biuletyn współczesnych dzieł obcych) - biuletynu zawierającego listę wszystkich najnowszych prac wydawanych za granicą i zbierającego

\footnotetext{
${ }^{7}$ P. Traniello, Le biblioteche italiane di oggi, Bolonia 2005, s. 77.
} 
informacje na ich temat, a w latach 1943-1981 sporządzała - wydawany w serii Indici e Cataloghi (Indeksy i katalogi) - Indice Generale degli Inkunaboli, a więc indeks generalny inkunabułów znajdujących się w zbiorach włoskich bibliotek. Od 1989 roku Biblioteca Nazionale Centrale di Roma stanowi również narodowe centrum badań manuskryptów i gromadzi u siebie mikrofilmy ze wszystkimi manuskryptami, jakie posiadają biblioteki na terenie Włoch ${ }^{8}$.

Istnienie aż ośmiu bibliotek narodowych, w tym dwóch centralnych, choć uzasadnione historycznie, jest kolejnym aspektem bibliotekarstwa włoskiego niezbyt dobrze ocenianym przez znawców tematu, zwłaszcza przez przywoływanego już Paolo Traniellego. Uważa on, że jest to następna przyczyna chaosu uniemożliwiającego sprawne funkcjonowanie tych instytucji. Szczególnie że brak im jednego centrum, które koordynowałoby wszystkie podejmowane przez nie działania. Jednym słowem, badacz sądzi, że błędem jest dzielenie funkcji biblioteki centralnej między dwie instytucje $e^{9}$ Potrzebę stworzenia jednej centralnej biblioteki, która skupiałaby w jednym miejscu najważniejsze funkcje, obecnie rozproszone między kilka bibliotek, zgłasza też w swoim artykule dwoje znanych bibliotekoznawców, Mauro Guerrini i Giovanna Frigimelica. Uważają oni, że ustanowienie takiego miejsca jest jednym z priorytetowych zadań dla współczesnych włoskich bibliotekarzy. Według nich byłby to duży krok w kierunku usprawnienia działalności sieci bibliotecznej na terenie $\mathrm{kraju}^{10}$.

Omawiając system funkcjonowania współczesnych włoskich bibliotek, nie można pominąć również kwestii egzemplarza obowiązkowego. W kraju na Półwyspie Apenińskim, tak jak w większości krajów europejskich, na wydawców nałożono obowiązek nieodpłatnego dostarczania do wybranych bibliotek druków, książek oraz dokumentów dźwiękowych i audiowizualnych. Prawo to funkcjonuje w zjednoczonych Włoszech od 1939 roku. Wtedy to powstała pierwsza ustawa dotycząca egzemplarza obowiązkowego: Norme per la consegna di esemplari degli stampati e delle publicazioni (Zasady przekazywania egzemplarzy druków i publikacji), zmodyfikowana następnie w 1945 roku. Zgodnie z tym aktem prawnym do przesyłania bezpłatnych publikacji do bibliotek zobowiązani byli drukarze, a nie - jak dziś - wydawcy. Mieli oni dostarczać pięć egzemplarzy obowiązkowych. Cztery z nich miały być przekazywane za pośrednictwem Prefektury do Biblioteki Narodowej w Rzymie, Biblioteki Narodowej

\footnotetext{
${ }^{8}$ M. Guerrini, op.cit.

${ }^{9}$ P. Traniello, Le biblioteche italiane..., s. 81.

${ }^{10}$ M. Guerrini, op.cit.
} 
we Florencji, stolicy prowincji wyznaczanej przez Ministerstwo Kultury oraz do biura premiera, który mógł zadecydować o oddaniu otrzymanej kopii do Biblioteki Narodowej w Rzymie, jako egzemplarza przeznaczonego do wypożyczania. Piąty egzemplarz był przekazywany za pośrednictwem Prokuratury Republiki do Ministerstwa Sprawiedliwości, które również mogło go oddać do wyznaczonej przez siebie biblioteki ${ }^{11}$.

Te dość skomplikowane zasady zostały zmienione 15 kwietnia 2004 roku. Ustalono wówczas nowe prawo egzemplarza obowiązkowego: Norme relative al deposito legale dei documenti di interesse culturali destinati all'uso pubblico (Zasady dotyczące egzemplarza obowiązkowego dokumentów o znaczeniu kulturalnym przeznaczonych do użytku publicznego). Jest ono uproszczone i bardziej odpowiadające współczesnym warunkom. Zgodnie z nowym prawem to wydawcy, a nie drukarze, są odpowiedzialni za dostarczenie bezpłatnych publikacji do bibliotek. Poza tym zwalnia ono Prefekturę i Prokuraturę Republiki z pośredniczenia w rozsyłaniu egzemplarza obowiązkowego i zmniejsza jego liczbę z pięciu do czterech. Dwa z nich mają być nadal przekazywane do centralnych bibliotek narodowych, dwa pozostałe pozostają w gestii regionów, decydujących o tym, którym bibliotekom znajdującym się pod ich zwierzchnictwem przekazać egzemplarz i według jakich reguł biblioteki te mają nim dysponować. Zakres egzemplarza obowiązkowego zostaje też powiększony o czasopisma, mapy, atlasy, druki muzyczne, druki ulotne, płyty, materiały zdigitalizowane, ale tylko te dostępne offline. Obecna włoska ustawa o egzemplarzu obowiązkowym, choć zmieniona i unowocześniona, zdaniem wielu bibliotekoznawców wciąż jeszcze nie do końca odpowiada współczesnym warunkom i z pewnością czeka ją jeszcze wiele modyfikacji i ulepszeń. Takie zdanie wyraża w swoim artykule Mauro Guerrini. Autor zauważa, że pomimo wielu pozytywnych aspektów nowej ustawy - takich jak: ustanowienie potrzeby archiwizowania dokumentów na poziomie państwowym i regionalnym, a więc w bibliotekach narodowych i w bibliotekach zarządzanych przez regiony, dokładne ustalenie, jakie typy dokumentów są przeznaczane na egzemplarz obowiązkowy, uproszczenie zasad ich dostarczania i rozporządzania nimi - nie spełnia ona wszystkich wymagań współczesnego bibliotekarstwa, a przede wszystkim sposobu traktowania źródeł elektronicznych, i potrzebuje dalszych modyfikacji i uzupełnieńn ${ }^{12}$.

W działalności współczesnych włoskich bibliotek ważną rolę odgrywa profesjonalne stowarzyszenie bibliotekarzy, podobne do polskiego

\footnotetext{
${ }^{11}$ P. Traniello, Legislazione..., s. 23-24.

${ }^{12}$ M. Guerrini, op.cit.
} 
Stowarzyszenia Bibliotekarzy Polskich. Jest nim AIB - Associazione italiana biblioteche, co można dokładnie przetłumaczyć jako Stowarzyszenie Włoskich Bibliotek. Jest to w środowisku włoskich bibliotekarzy bardzo ważna instytucja. Została założona w 1930 roku. Obecnie liczy około 4000 członków, głównie bibliotekarzy, choć członkostwo nie jest uzależnione od wykonywania tego zawodu. Wystarczy zainteresowanie zagadnieniami włoskiego bibliotekoznawstwa. Dlatego przystępują do niego również studenci, firmy prywatne, a nawet biblioteki zagraniczne. Głównymi zadaniami, podobnie jak w przypadku Stowarzyszenia Bibliotekarzy Polskich, są promocja bibliotek i organizowanie rozmaitych konferencji, kongresów i forów dyskusyjnych. Co roku członkowie zrzeszenia są gospodarzami Narodowego Kongresu Włoskich Bibliotekarzy. AIB zajmuje się też wydawaniem publikacji o tematyce bibliotekoznawczej, w tym dwóch periodyków: kwartalnika „Bolletino AIB” (Biuletyn AIB) oraz „AIB Notizie" (Wiadomości AIB), newslettera przekazującego najnowsze informacje na temat działalności stowarzyszenia. Struktura AIB opiera się na dwóch rodzajach komitetów wykonawczych działających na szczeblu państwowym i regionalnym: Comitato Esecutivo Nazionale - CEN (Narodowy Komitet Egzekucyjny) i Comitati Esecutivi Regionali - CER (Regionalne Komitety Egzekucyjne). Każdy komitet składa się z siedmiu członków wybieranych co trzy lata. Przewodniczącym pierwszego z nich jest obecnie, wspominany już w niniejszym artykule, Mauro Guerrini. Działania komitetów regionalnych koordynuje The Consiglio Nazionale dei Presidenti Regionali - CNPR (Narodowa Rada Regionalna) ${ }^{13}$.

Stowarzyszenie posiada portal internetowy AIB-WEB, w dwóch wersjach językowych: włoskiej i angielskiej, na którym można znaleźć wiele informacji dotyczących jego działalności, statutu, struktury organizacyjnej, publikacji, najnowszych wydarzeń, które organizuje lub którym patronuje. Jest to ponadto cenne źródło ogólnych informacji na temat włoskich bibliotek, zasad ich funkcjonowania i aktualnego prawa bibliotecznego. Umieszczone są tam też linki do europejskich katalogów online, baz danych, bibliotek cyfrowych i innych zasobów elektronicznych. Można się również dowiedzieć, jak wygląda kariera bibliotekarza we Włoszech i co należy zrobić, aby nim zostać. Portal poświęca temu zagadnieniu zakładkę AIB-WEB - Formazione professionale (Kształcenie zawodowe), na której podaje listę kierunków na wyższych uczelniach, uwzględniających $\mathrm{w}$ swoich programach kształcenie $\mathrm{w}$ kierunku bibliotekoznawstwa, archiwistyki, paleografii, biografistyki, na poziomie

${ }^{13}$ AIB. Vita dell Associazione, [online], [dostęp: 5.03.2011], dostępny w internecie: http://www.aib.it/aib/cen/org.htm3. 
studiów licencjackich, magisterskich i podyplomowych ${ }^{14}$. Wyższe wykształcenie jest bowiem we Włoszech, podobnie jak w Polsce, podstawowym kryterium decydującym o możliwości rozwoju w zawodzie bibliotekarza. Profesja ta nie ma jednak ściśle ustalonej ścieżki awansu zawodowego. Zatrudnianie personelu zależy od sposobu administrowania daną biblioteką. Jest to kolejna kwestia często uważana za minus włoskiego bibliotekarstwa, którą należy w przyszłości uporządkować, wprowadzając określone zasady.

Wszystkie powyższe uwagi świadczą o tym, że system funkcjonowania współczesnych włoskich bibliotek nie jest idealny. Jego wady i niedociągnięcia wymagają wielu zmian i modyfikacji. Jak wspomniałam, brak we Włoszech jednolitego prawa, którym podporządkowane byłyby wszystkie biblioteki i które usprawniałoby ich działania w narodowej sieci bibliotecznej, brak także scentralizowanego ośrodka, który koordynowałby ich pracę, a większość problemów, z jakimi biblioteki się borykają wynika z uwarunkowań historycznych. Na Półwyspie Apenińskim zjednoczony kraj funkcjonuje od niedawna i wciąż widoczne są głębokie podziały. Znaczne odmienności kulturowe, społeczne i gospodarcze można dostrzec w północnej i południowej części kraju, co przekłada się też na różnice w jakości działania bibliotek. W rejonach takich jak Lombardia, Piemont, Emilia-Romania bibliotek jest więcej, są one nowocześniejsze, lepiej wyposażone, a także bardziej wykorzystują najnowsze technologie informatyczne. Wiele bibliotek znajdujących się na południu ma pod tym względem duże zaległości. Często nie mają nawet swoich stron internetowych. Nie chodzi tutaj tylko o małe biblioteki publiczne, ale też o biblioteki narodowe znajdujące się w Cosenzy, Potenzy, Neapolu czy Bari. Mimo że z początkiem XXI wieku zaczęło przybywać na tym terenie nowych placówek przeznaczonych dla ludzi lubiących i chcących czytać i uczyć się, wciąż w tej kwestii jest wiele do nadrobienia ${ }^{15}$.

Wynikające z powyższych rozważań wnioski świadczą o tym, że włoskie biblioteki straciły wiele ze swojej dawnej świetności i znajdują się obecnie w nie najlepszej kondycji. Mimo wszystko jednak należy zwrócić uwagę na to, że w ciagu ostatnich lat w Italii poczyniono kroki ku temu, aby wyciagnąć włoskie bibliotekarstwo z regresu i uczynić biblioteki instytucjami uczącymi się, ulepszającymi i dorównującymi europejskim standardom. Przykładem mogą też być zainicjowane w ostatnim czasie we Włoszech, pod patronatem Direzione Generale per le Biblioteche, gli Instituti Culturali

${ }^{14}$ AIB. Formazione Proffessionale [online], [dostęp: 5.03.2011], dostępny w internecie: http://www.aib.it/aib/form/form.htm3.

${ }^{15}$ P. Traniello, Le biblioteche italiane..., s. 77. 
e il Diritto d'Autore, projekty wykorzystujące nowoczesne technologie informatyczne i rozwijające zaplecze informacyjne kraju, takie jak:

1. Bibliotecha Digitale Italiana - BDI (Włoska Biblioteka Cyfrowa) - powstała w 1999 roku, zajmuje się elektronicznym udostępnianiem najciekawszych zbiorów bibliotecznych znajdujących się we Włoszech, w skład których wchodzą czasopisma, materiały kartograficzne, fotografie, partytury muzyczne, prace doktorskie i inne; z roku na rok przybywa dokumentów ${ }^{16}$.

2. Portale Internet Culturale (Internetowy Portal Kulturalny) - rezultat projektu La Bibliotecha Digitale Italiana e il Network Turistico Culturale - BDI \& NTC (Włoska Biblioteka Cyfrowa i Sieć Turystyczno-Kulturalna). Portal oferuje zintegrowany dostęp do zdigitalizowanych zasobów bibliotek, archiwów i innych włoskich instytucji kulturalnych. W założeniu ma służyć upowszechnianiu dostępu do bogatego dziedzictwa narodowego Włoch. Oprócz dostępu do zbiorczych katalogów bibliotek, kolekcji manuskryptów, starych druków, partytur czy map portal daje możliwość obejrzenia wystaw pokazywanych na żywo w muzeach, bibliotekach i innych instytucjach oraz elektronicznego zwiedzania różnych miejsc czy zabytków.

3. Progetto Libro Parlato (Projekt „książka mówiona”) - projekt, który ma na celu wprowadzenie w 24 bibliotekach na terenie Włoch oferty audiobooków mających ułatwić korzystanie z literatury osobom niewidomym i niedowidzącym ${ }^{17}$.

4. Sito del Centro per il Libro e la Lettura (Portal Centrum Książki i Lektury) - portal centrum zajmującego się promowaniem literatury i czytelnictwa we włoskim społeczeństwie, zarówno wśród dorosłych, jak i wśród dzieci. Są tu zamieszczone informacje i linki dotyczące rozmaitych imprez i wydarzeń kulturalnych, targów książki, festiwali, nagród literackich i przyznawanych za działalność wspierającą czytelnictwo, książek dostępnych online i bibliotek cyfrowych. Można się też tu zapoznać z kwestią prawa autorskiego czy prawa egzemplarza obowiązkowego ${ }^{18}$.

${ }^{16}$ Direzione Generale per le Biblioteche, gli Istituti Culturali e il Diritto d'Autore, Biblioteca Digitale Italiana-BDI [online], [dostęp: 5.03.2011], dostępny w internecie: http://www.librari.beniculturali.it/genera.jsp?s=31\&l=it.

17 Direzione Generale per le Biblioteche, gli Istituti Culturali e il Diritto d'Autore, Progetto Libro Parlato [online], [dostęp: 5.03.2011], dostepny w internecie: http:// www.librari.beniculturali.it/generaNews.jsp?id=43\&lingua=it\&l=it.

18 Strona główna Centro per il Libro e la Lettura [online], [dostęp: 1.03.2011], dostępny w internecie: http://www.cepell.it/sezioni.xhtm. 
5. Cultura Italia - portal, który na największą do tej pory skalę udostępnia zasoby elektroniczne bibliotek, archiwów, muzeów i innych miejsc zajmujących się gromadzeniem i przechowywaniem włoskiego dziedzictwa narodowego. Współpracuje z europejską biblioteką wirtualną Europeana ${ }^{19}$.

Warto też wspomnieć o ciekawej inicjatywie społecznej, w którą włączyli się przedstawiciele środowiska bibliotekarskiego we Włoszech i członkowie AIB, przy współpracy z Associazione Culturale Pediatri (Kulturalne Stowarzyszenie Pediatrów) i Centrum Zdrowia Dziecka, a którą jest projekt Nati per leggere (Urodzeni czytelnicy). Odwołując się do ustaleń współczesnych pedagogów i psychologów, którzy podkreślaja, jak ważne dla rozwoju dziecka jest jak najwcześniejsze oswajanie go z książką, inicjatorzy tej akcji - korzystając z pośrednictwa lekarzy pediatrów - przekazują dzieciom zestawy książek. Aby obniżyć ich cenę, podpisuje się specjalne umowy z wydawnictwami specjalizującymi się w wydawaniu literatury dziecięcej, które zobowiązują się sprzedawać książki po niższych kosztach (około 3-3,5 euro za sztukę). Zaczęto też tworzyć minibiblioteczki w przychodniach pediatrycznych, żłobkach, przedszkolach i innych instytucjach wsparcia rodziców i rodzin, a także zostawiać tam wskazówki bibliograficzne dla rodziców, którzy zamierzają zaczać czytać swojemu dziecku, ale nie wiedza, co wybrać z bogatej oferty wydawniczej. W bibliotekach inicjuje się akcje głośnego czytania dzieciom przez bibliotekarzy i wolontariuszy. Według przeprowadzonych ankiet trwająca już od około 10 lat akcja przyniosła bardzo dobre rezultaty. Odnotowano godne uwagi wyniki: na północy zainteresowanie czytelnictwem wzrosło z 28 do $39,9 \%$, a na południu z 12 do $32 \%{ }^{20}$.

Inną społeczną inicjatywą podjętą przez włoskich bibliotekarzy jest projekt In-novate library. Jest to reakcja na coraz większą liczbę imigrantów przybywających na teren Włoch. Projekt ma pomóc im przystosować się do życia w obcym kraju, odmiennej kulturze i zintegrować się z resztą społeczeństwa. Jedna z podjętych w tym celu akcji, o nazwie wwww. Extra-ordinary woman, skierowana jest do kobiet, imigrantek, będących matkami. W bibliotekach są organizowane dla nich kursy językowe, spotkania, warsztaty, kursy komputerowe, wycieczki po okolicy służące lepszemu poznaniu miejsca, w którym mieszkają. W czasie zajęć ich dziećmi zajmują się wolontariusze w wyznaczonych do tego miejscach. Druga część projektu jest przeznaczona dla dzieci imigrantów, które przybyły do

${ }^{19}$ R. Caffo, Italia nei progetti di cooperazione Europea: Risultati, Critica e Prospective, w: Il Mondo in biblioteca, la biblioteca nel mondo, red. M. Belotti, Milano 2010, s. 53-56.

${ }^{20}$ Rapporto sulle biblioteche italiane 2009-2010, red. G. Solimine, Roma 2010, s. 55-67. 
Włoch wraz z rodzicami lub urodziły się już na terenie republiki. Organizowane są dla nich zajęcia kulturalne i artystyczne, mające wspomagać ich rozwój i przystosowanie do życia w obcym kraju. Inną ciekawą akcją w ramach projektu In-novate library są organizowane pod hasłem: La bibliotecha $e^{\prime}$ fuori (Biblioteka jest na mieście) przejazdy ulicami miast tzw. bibliobusu oferującego usługi biblioteczne poza murami bibliotek ${ }^{21}$.

We Włoszech powstaje też coraz więcej ciekawych, nowoczesnych, dobrze wyposażonych bibliotek, wykorzystujących w swojej pracy najnowsze technologie informatyczne. Przykładem może być powstała w 2001 roku biblioteka publiczna Biblioteca Salaborsa w Bolonii. W swojej misji została ona określona „biblioteką multimedialną”, oferującą udostępnianie zbiorów nie tylko w formie tradycyjnej, ale też przez wykorzystanie wszelkiego typu materiałów multimedialnych, zgodnie z zasadą "leggere, ascoltare, guardare, cliccare" (czytać, słuchać, patrzeć, klikać). W bibliotece dostępne są: literatura na CD-ROM-ach, w postaci audiobooków, e-booków, zbiór płyt CD z wieloma rodzajami muzyki, kolekcja filmów na DVD i VHS, zawierająca klasykę kina, dzieła najważniejszych reżyserów z całego świata, a także seriale, kreskówki, sztuki teatralne, opery, balety, musicale itp. ${ }^{22}$. Biblioteca Salaborsa ma też ciekawą graficznie i łatwą w wyszukiwaniu informacji stronę internetową. Można się z niej dowiedzieć o nowoczesnych usługach świadczonych przez instytucję, takich jak: zapisy i opłaty online, zapytaj bibliotekarza, zaproponuj kupno książki; ciekawa jest też zakładka: "proposte della biblioteca” (biblioteka poleca), zawierająca „wizytówki” najnowszych nabytków biblioteki, na które warto zwrócić uwagę czytelnika ${ }^{23}$.

Niestety brak środków finansowych stanowi często blokadę rozwoju większej liczby tego typu nowoczesnych instytucji we Włoszech. Z tego powodu przedłuża się $w$ czasie realizacja dwóch ciekawych projektów zainicjowanych około 2000 roku.

Pierwszy z nich to budowa nowej biblioteki miejskiej w Turynie, związana z szerszym procesem restrukturyzacji obszaru miejskiego i modernizacją kolei. W założeniach pomysłodawców biblioteka ma być rozwinięta informatycznie, zaopatrzona w nowoczesny sprzęt, ma zapewniać wolny dostęp do półek. Jest też projekt utworzenia w niej sali teatralnej, która miałaby wspomagać działalność kulturalną instytucji ${ }^{24}$. Mimo jednak że

${ }^{21}$ Por. ibidem, s. 34.

${ }^{22}$ P. Traniello, Le biblioteche italiane..., s. 69.

${ }^{23}$ Strona główna Biblioteki Salaborsa [online], [dostęp: 1.03.2011], dostępny w internecie: http://www.bibliotecasalaborsa.it/home.php.

${ }^{24}$ P. Traniello, Le biblioteche italiane..., s. 68. 
od pierwszych rozmów na temat stworzenia tej biblioteki minęło dziesięć lat, projekt nadal nie został sfinalizowany i wciąż toczą się wokół niego dyskusje.

Podobnie od dłuższego czasu jest w realizacji drugi projekt - budowa BEIC - Biblioteca Europea di Informazione e Cultura (Europejska Biblioteka Informacji i Kultury) w Mediolanie. Jest to bardzo drogie przedsięwzięcie (ostateczna realizacja ma kosztować około 260 milionów euro). Idea zrodziła się w 2000 roku i zainicjował ją profesor prawa Antonio Padoa Schioppa. Chodzi o wybudowanie ogromnej biblioteki o interdyscyplinarnym, hybrydowym i multikulturowym charakterze, z wolnym dostępem do półek, która w sposób najpełniejszy i najbardziej wszechstronny ma dostarczać użytkownikowi poszukiwanych informacji, łącząc udostępnianie tradycyjnych materiałów drukowanych $\mathrm{z}$ dostępem do najnowszych zasobów elektronicznych. Nowoczesny architektonicznie, czteropiętrowy budynek, projektu architekta Petera Wilsona, ma być gotowy na przyjęcie dużej liczby czytelników zainteresowanych różnymi dziedzinami wiedzy. Szczegóły dotyczące tego monumentalnego projektu można poznać na specjalnej stronie internetowej przygotowanej w języku włoskim i angielskim ${ }^{25}$. Inicjatywę popierają nie tylko lokalne władze Mediolanu, ale też cały region Lombardii, uniwersytety mediolańskie oraz Fundacja Cariplo. Pomimo takiego entuzjazmu projekt od dziesięciu lat czeka na ukończenie, które - z powodu braku środków finansowych ciągle się odwleka.

Wnioski, które nasuwają się z tego krótkiego przeglądu, nie mogą być szczególnie odkrywcze. Biblioteki włoskie do jakiegoś stopnia borykają się z tymi samymi problemami co większość wielkich nowoczesnych bibliotek europejskich: wdrażanie najnowszych technologii, wrażliwość na nowinki informatyczne, interesujące projekty, które promują czytelnictwo, i chroniczny brak środków finansowych uniemożliwiający bądź przedłużający w nieskończoność ich realizację. W przypadku Włoch dochodzą jednak pewne kłopoty, które są lokalną osobliwością. Historycznie uzasadnione, dziś często kłopotliwe podziały administracyjne i wynikające $\mathrm{z}$ nich niejasne relacje prawne między centrum a poszczególnymi regionami to dodatkowe wyzwania, którym muszą sprostać współcześni włoscy bibliotekarze. Wbrew pozorom nie są to problemy małe. Być może kiedyś nie miały one takiego znaczenia, ale dziś, gdy cały świat biblioteczny dąży do unifikacji i standaryzacji, gdy wzrasta rola centrum,

25 Strona główna projektu Biblioteca Europea di Informazione e Cultura [online], [dostęp: 1.03.2011], dostępny w internecie: http://www.beic.it/wps/wcm/connect/ Beic/Site00/Home/. 
stają się rzeczywistą przeszkodą i poważnym problemem, który Włosi, jeśli chcą się liczyć w światowym bibliotekarstwie, muszą jak najszybciej rozwiązać.

KINGA ADAMIAK

\title{
Modern Italian libraries - between tradition and modernity
}

\begin{abstract}
Aвstract. For centuries, lands currently belonging to the Republic of Italy boasted the greatest and the most illustrious libraries in Europe. From the Middle Ages to Renaissance, they developed extensively and were dominant in the Old World. The present article, however, concentrates on modern Italian libraries and provides an extensive review of their functioning today. The following issues are covered in the discussion: types of libraries and their cooperation, legal circumstances, the activity of national libraries, library associations and their initiatives and projects aimed at utilization of state-of-the-art IT infrastructures in librarianship. The article also emphasizes strong and weak points of Italian librarianship and ponders on the following: What is the role of Italian libraries today when they are evidently past their prime times? Can the libraries in question meet the requirements of modern times?
\end{abstract}

Key words: libraries, librarians, problems of modern libraries, Italy, Italian libraries, modern Italian libraries. 
